\title{
Developing the Knowledge Base of the Profession: Research in School Librarianship
}

\author{
Laurel A. Clyde \\ Faculty of Social Science \\ University of Iceland \\ 101 Reykjavik, \\ Iceland \\ anne@hi.is
}

\begin{abstract}
This paper reports on one aspect of a wider longitudinal study of "Research and Researchers in School Librarianship". Research articles and conference papers published in English over the ten-year period 1991 to 2000 in the field of school librarianship were analyzed to identify the country of the research, the type of publication in which the research was reported, the research methods used, and the aspects of school librarianship that were investigated. Changes and trends in the research through the decade are described and emerging issues are discussed. The methodology draws on studies that looked at aspects of research in the broader field of library and information science generally, in an international context.
\end{abstract}

\section{Background}

Research in school librarianship is currently "on the agenda" of decision-makers, funding authorities, school systems, and professional associations, for a number of reasons. At a time of cuts in school library funding in places like California (Bell, 2002) and Canada (CBC News, 2002), the question of whether or not "school libraries make a difference" becomes vitally important. While this question is being addressed through research projects that are under way now, the views that people hold about the quality of research in school librarianship will have an influence on the way in which the results of this research are received. Within teaching and librarianship, there is a new emphasis on evidence-based practice, as the success of Ross Todd's virtual conference session at the IASL 2001 conference clearly demonstrated. "Evidence-based practice, where day by day practice is directed towards demonstrating the tangible power of teacher librarians' contributions to schools' learning goals, is critical to the future sustainability of the profession..." (Todd, 2002, p.30). Evidence is collected through, among other things, action research. Action research can "help refine our teaching practice [and] give weight to our beliefs and intuitions" (Buckley, 1995, p.25). Further, school librarians need to engage in "reflection upon research findings and how these findings can improve practice" (Henri, 1998, p.33). And finally, research develops and reinforces the knowledge base of the profession; a strong research climate is important if the profession is to develop strategies to deal with emerging problems and to move forward. As Calvert (1990, p.20) has said, "...research and its outward manifestation as scholarly literature is a vital ingredient of a healthy profession". The ongoing research described in this paper is investigating research in the field of school librarianship, the characteristics of that research, and the people who undertake the research. 
A paper given in the Research Forum at the 2001 conference of IASL in Auckland, New Zealand (Clyde, 2001a), provides the background to the research reported here. That paper described a series of inter-linked and mutually-dependent studies that are designed to address various aspects of the broad topic of "Research and Researchers in School Librarianship". These studies are the result of concerns expressed in the professional and research literature about the quantity and quality of research in school librarianship (see, for example, Henri, 1998; Katzer, 1989; Stroud, 1982) and about both those factors that facilitate research and perceived barriers to research in school librarianship (Clyde, 1994). The broad aims identified for the series of studies of research and researchers in school librarianship are:

1. To provide an overview of the current state-of-the-art of research in school librarianship;

2. To compare the current state-of-the-art with the results of similar work undertaken in 1995/1996, in order to identify trends and developments over a decade;

3. To identify the current active researchers in the field of school librarianship internationally, as the basis for a survey;

4. To identify and investigate issues associated with research in school librarianship, including quality/quantity issues and issues associated with perceived barriers to research in school librarianship.

More specific and detailed aims have been developed for each of the studies that have been or will be undertaken as part of the overall research project. The particular section of the research that is reported on here, relates to the first and second broad aims: it takes the form of a longitudinal comparative study of research in the field of school librarianship over a decade, 1991 to 2000 inclusive. A preliminary verbal report of this work (Clyde, 2001b), presented in the Research Forum at the 2001 conference, was based only on data from 1991 to 1995 and 1995 to 1999 . The inclusion of the 2000 data in this 2002 paper means that some of the comments made in 2001 for the period to the end of 1999 need to be reconsidered in the light of the 2000 data. Within the broad aims identified for the research as a whole, the aims for this particular aspect of the research are:

1. To identify the places where research in school librarianship (in the form of research articles and conference papers) is reported.

2. To identify any changes over the decade in the type of publication in which the results of research in the field of school librarianship are reported.

3. To identify trends in the quantity of research reported in research articles and conference papers in the field of school librarianship.

4. To identify the countries in which research is being undertaken and published or about which research is being undertaken and published, in the field of school librarianship.

5. To identify the research methodologies that are being used by researchers in the field of school librarianship and to investigate any changes over time.

6. To identify the topics that are being studied by researchers in the field of school librarianship and to investigate any changes over time.

There are some limits to this study, including some that are the result of limits to the earlier work (for example, Clyde, 1996) on which the current research is based. Only published research is being studied, in the form of research articles in professional and research journals, and papers in published conference proceedings and other collections of articles and papers. The reasons for this will be discussed below under "Methodology". The studies are further limited to research published in English, regardless of the country in which the research was carried out or published. The potential effects of these limitations will be discussed as part of the analyses. 


\section{Methodology}

A detailed description of the research methodologies used for the project as a whole is available elsewhere (Clyde, 2001a); only a summary of the data collection and analysis strategies that relate to this particular aspect of the overall work will be provided here. Important questions that had to be addressed before data collection could begin included "What is research?" and "What is school librarianship?". An earlier study in which the author was involved, of research in library and information science in Iceland (Pálsdóttir, et al., 1994), established criteria for selecting research articles and papers in library and information science generally, while the author's work for a 1996 IASL publication (Clyde, 1996) established boundaries for the narrower field of "school librarianship". An extensive literature review provided background, particularly in the form of studies that had investigated research in library and information science and related fields, and research into particular aspects of library and information science.

The 1996 IASL publication project referred to above, in particular, had a strong influence on the present research: it not only effectively established some of the parameters for the work but also provided some of the data. Sustaining the Vision: A Collection of Articles and Papers on Research in School Librarianship (Clyde, 1996) was published by the Association in honour of Jean E. Lowrie. The IASL Board had specified that the articles and papers selected for inclusion should already have been published, and thus, in most cases, have passed through a peer review process. It was also decided at this stage that the book should include only articles and papers published in English in the preceding five years. In addition, it was decided that the articles and papers should describe work carried out within the general field of school librarianship; "material from related fields like school administration, children's literature, audiovisual media, children's reading, and/or public/community library services for young people was to be included only if there was strong evidence of school library involvement" (Clyde, 1996, p.5). The editor's introduction to the book notes that "more than 70 periodical titles (professional journals and newsletters) from more than 50 countries were scanned" for potential articles for inclusion, along with relevant conference proceedings (Clyde, 1996, p.6). Publications covered the years 1990 to 1995 inclusive. The database of articles and papers that resulted, formed the basis for further data collection for the whole period 1991 to 2000.

Studies of research in the field of library and information science in general have been based on a number of different reporting formats, for example research articles and papers (Järvelin \& Vakkari, 1990), conference papers (Snelson \& Talar, 1991), theses and dissertations (Yontar, 1995; Stroud, 1982), other unpublished research reports (Blöndal, 1997), and entries in databases of current research. In part, the selection of published research articles and conference papers as the focus for the present study reflects the relative accessibility of research reports in these formats, as against theses, dissertations, and unpublished research reports. Entries in databases of current research (such as CRLIS) generally deal with projects in progress and thus are outside the scope of this study, which deals with completed research. The selection of published research articles and papers also reflects a conviction that publication is an important part of the research process for a profession as a whole, as well as an indicator of the commitment of the researchers.

A further consideration in the present study was that the Finnish researchers Järvelin and Vakkari $(1990 ; 1993)$ have established widely-accepted (Yontar \& Yalvaç, 2000, p.41) techniques for studying published research output (in the form of articles and papers) in library and information science, in such a way that the research output can be compared 
across time and across countries. Järvelin and Vakkari used their own methodology to study international research in library and information science generally through articles in 37 core journals (Järvelin \& Vakkari, 1990). They subsequently updated this work through a longitudinal comparative study (Järvelin \& Vakkari, 1993). Researchers who have used their methodology for national studies have included Cano and Rey (1993) in Spain; Pálsdóttir, et al. (1994; 1997) and Gu>brandsdóttir, et al. (2001) in Iceland; Rochester (1995) in Australia; Layzell Ward (1997) in the United Kingdom; and Yontar (1995) in Turkey. Rochester and Vakkari (1998) compared these and other country studies that used the Järvelin and Vakkari methodology and through their analysis looked at national differences and trends. It was hoped that using the techniques and classifications of Järvelin and Vakkari (as much as possible) to study research in one area of library and information science would mean that the results of this research would be comparable with other studies that use the strategies developed by Järvelin and Vakkari; it also provided an opportunity to test Järvelin and Vakkari's classifications in a specific area of library and information science, namely school librarianship.

For this research on research and researchers in school librarianship, all issues of journals scanned for the 1996 IASL project were again scanned for the period 1995 to 2000 , as were the relevant volumes of conference proceedings. Online searches were undertaken of ERIC, LISA, Library Literature and other databases on DIALOG; of selected databases on OCLC; of journals on Emerald and other services; and using Internet search engines. Whenever a potentially relevant article was found in a journal that had not previously been scanned, then the whole run of the journal from 1991 to 2000 was scanned. Published bibliographies (for example, Coleman, 2000; Satija, 1994) and guides to the journal literature (for example, Singh \& Singh, 1990) also provided leads to likely articles and papers. Again, if a potentially relevant article was identified in one issue of a journal, then all issues of the journal for the decade were scanned. Information recorded about each article or paper included bibliographic citation, country in or about which the research was undertaken, research methods used, and the topic of the research. Additional notes were made where necessary, for example to indicate where the research had been published previously in another form, or the relationship of the research to a particular project, or any other relevant factors. The articles and papers for 1995 were recorded twice, once in 1996 and once in 2000, as a check to ensure that the data recording techniques were applied consistently even though there was a five-year gap between the 1996 and 2000 analyses. Despite the passage of time, the correlation was 96 per cent over the articles and papers included for 1995.

\section{Reporting Research In School Librarianship 1991-2000}

In this section, findings related to three of the aims of this particular aspect of the overall research will be discussed: the places where research in school librarianship (in the form of research articles and conference papers) is reported; the changes over time in the type of publication in which the research results are reported; and trends related to the quantity of research publishing in the field of school librarianship.

In all, 170 research articles and papers in the field of school librarianship, published in English, were identified for the five years 1991 to 1995, and 314 for the five years 1996 to 2000 (an increase of more than $100 \%$ on the first five years). A total of 484 research articles and papers were found for the decade as a whole (see Table 1 below). Of those, 389 were research articles, and 95 were research-based conference papers. 
Table 1

Research Articles and Papers in School Librarianship, 1991-2000

\begin{tabular}{l|lll}
\hline & $1991-1995$ & $1996-2000$ & $\begin{array}{l}\text { Total Numbers: } \\
1991-2000\end{array}$ \\
\hline Research Articles & 154 & 235 & 389 \\
Research Papers & 16 & 79 & 95 \\
\hline TOTALS & 170 & 314 & 484 \\
\hline
\end{tabular}

The large increase in the number of research-based conference papers published through the second lustrum (79 in the years 1996 to 2000, as against 16 in the years 1991 to 1995) can be accounted for by the establishment of the international Research Forums held in conjunction with each annual conference of IASL since Vancouver in 1997. If the 65 papers presented at the IASL Research Forums are removed from the total of papers for 1996-2000, then the remaining number of 14 published papers is very close to the 16 published from 1991 to 1995 . Across the decade, the remaining research papers were found in the published proceedings of five conferences - IASL's own conference proceedings, the papers from the School Section sessions at IFLA (International Federation of Library Associations and Institutions) conferences, the proceedings of the Australian Library and Information Association and Australian School Library Association conferences, and the proceedings of the annual "Online Information" conferences in London (see Appendix 1).

Where are the research articles (as distinct from conference papers) published? The table in Appendix 1 shows that in the decade of the 1990s, they appeared in some 55 journals. However, 19 of those journals published only one research article related to school librarianship in the ten-year period, while a further eight journals published only two relevant articles. This means that a considerable number of the research articles in school librarianship are scattered across a large number of journals, some of which are not very well known outside the area where they are published and some of which are hard to find except in major research collections. It can therefore be difficult for people to get an overview of the published research in school librarianship.

On the other hand, just two journals have been the major focus for research publishing in the field of school librarianship: IASL's School Libraries Worldwide, and the American Association of School Librarians' journal School Library Media Research (including articles published under its former name, School Library Media Quarterly). Together these two journals published 32.9 per cent of all the research articles through the decade. This is despite the fact that School Libraries Worldwide only commenced publication in 1995, and despite an analysis which shows that only around 54 per cent of articles in School Libraries Worldwide were research articles, in terms of the definition used for this project (see Table 2). Clearly, the Association's School Libraries Worldwide, which in 2001 became a fully research-based journal, has the potential to be a major force in research publishing in school librarianship in the immediate future. 
Table 2

Research Articles in School Libraries Worldwide

\begin{tabular}{l|lll}
\hline ISSUE & $\begin{array}{l}\text { Number of Research } \\
\text { Articles }\end{array}$ & Number of Other Articles & $\begin{array}{l}\text { Total Number of Articles } \\
\text { (excluding editorials) }\end{array}$ \\
\hline 1(1) January 1995 & 7 & - & 7 \\
1(2) July 1995 & 1 & 3 & 4 \\
2(1) January 1996 & 2 & 7 & 9 \\
2(2) July 1996 & 3 & 1 & 4 \\
3(1) January 1997 & 2 & 5 & 7 \\
3(2) July 1997 & 4 & 3 & 7 \\
4(1) January 1998 & 4 & 2 & 6 \\
4(2) July 1998 & 2 & 8 & 10 \\
5(1) January 1999 & 8 & - & 7 \\
5(2) July 1999 & 7 & 1 & 8 \\
6(1) January 2000 & 2 & 11 & 13 \\
6(2) July 2000 & 7 & 1 & 8 \\
\hline TOTALS & $49(53.8 \%)$ & $42(46.1 \%)$ & $91(100 \%)$ \\
\hline
\end{tabular}

Note 1: The January 2000 issue was primarily devoted to "A Day in the Life...", descriptive stories from school library personnel around the world. There were only four regular articles in the issue, of which two were research articles. It was thus not a typical issue of the journal.

\section{Geographical Characteristics of the Research Studied}

The fourth aim of this particular part of the research project was to "identify the countries in which research is being undertaken and published or about which research is being undertaken and published, in the field of school librarianship". Although the aim is apparently a simple one - to get an indication of the countries that make significant contributions to the research literature - there are problems that arise when research output is analysed in this way in an international context. The "country of research" or "country of researcher" has been defined in different ways in the past, all of which present difficulties, especially in a large project.

Hawkins (2001) in his study of electronic journals, classified articles by "country of origin" of the author, from the address or affiliation given on the article; when this was not available on the article, it was collected in other ways. However, in a longitudinal study, authors' affiliations will change; in addition, some authors write while temporarily affiliated with an institution in another country, and some work in more than one country. It is common for foreign doctoral students in countries like the United States and the United Kingdom to write a thesis about a topic related to their home country and even to publish articles based on it, while still living abroad. There are researchers (including the author) who undertake projects in countries other than the one in which they hold a full-time position. The IASL definition of "country of residence" (the main country in which the person currently works) was of little use for a longitudinal study, particularly so when people were moving to new jobs in other places, or were publishing research about a country after having moved on to a new country. It is difficult to use citizenship as the criterion; in any case, some people have dual or even triple citizenship. Country of birth has been suggested (see Clyde, 2001b) as a way of classifying authors; however, this information may not be readily available for some authors, and in any case there are people who have lived for only a very short time in their country of birth and may not even speak the language of that country. In the end it was decided to use the country about which the article or paper was written as the classification, since this at least gave an indication of those places where the research was richest. However, this means that the people publishing the research may not be resident in that country, nor may they necessarily be a citizen of that country; in addition, an author might do work about 
several countries. The patterns behind this will become clearer when the authors themselves are studied in the next phase of this project.

Table 3

Research Articles and Papers 1991-2000, By Country Studied

\begin{tabular}{|c|c|c|c|}
\hline COUNTRY & $1991-1995$ & $1996-2000$ & $\begin{array}{l}\text { Total Number, } \\
1991-2000\end{array}$ \\
\hline USA & $73(42.9 \%)$ & $128(40.8 \%)$ & $201(41.5 \%)$ \\
\hline Australia & $32(18.8 \%)$ & $51(16.2 \%)$ & $8317.1 \%)$ \\
\hline Canada & $14(8.2 \%)$ & $28(8.9 \%)$ & $42(8.7 \%)$ \\
\hline International & $5(2.9 \%)$ & $34(10.8 \%)$ & $39(8.1 \%)$ \\
\hline United Kingdom & $12(7.1 \%)$ & $18(5.7 \%)$ & $30(6.2 \%)$ \\
\hline South Africa & $5(2.9 \%)$ & $12(7.1 \%)$ & $17(3.5 \%)$ \\
\hline Israel & $3(1.8 \%)$ & $9(2.9 \%)$ & $12(2.5 \%)$ \\
\hline New Zealand & $1(0.5 \%)$ & $8(2.5 \%)$ & $9(1.9 \%)$ \\
\hline Nigeria & $8(4.7 \%)$ & $1(0.3 \%)$ & $9(1.9 \%)$ \\
\hline Sweden & $4(2.3 \%)$ & $2(0.6 \%)$ & $6(1.2 \%)$ \\
\hline Iceland & 2 & 3 & 5 \\
\hline Iran & 4 & - & 4 \\
\hline Botswana & - & 3 & 3 \\
\hline Fiji & 1 & 2 & 3 \\
\hline Ghana & 1 & 1 & 2 \\
\hline Jamaica & - & 2 & 2 \\
\hline Malaysia & 1 & 1 & 2 \\
\hline Denmark & - & 1 & 1 \\
\hline Finland & - & 1 & 1 \\
\hline France & - & 1 & 1 \\
\hline Hong Kong & 1 & - & 1 \\
\hline Japan & - & 1 & 1 \\
\hline Kenya & 1 & - & 1 \\
\hline Korea & - & 1 & 1 \\
\hline Latvia & - & 1 & 1 \\
\hline Lithuania & - & 1 & 1 \\
\hline Namibia & 1 & - & 1 \\
\hline The Netherlands & - & 1 & 1 \\
\hline Norway & - & 1 & 1 \\
\hline Papua New Guinea & - & 1 & 1 \\
\hline Sierra Leone & - & 1 & 1 \\
\hline Taiwan & 1 & - & 1 \\
\hline TOTALS & $170(100 \%)$ & $314(100 \%)$ & $484(100 \%)$ \\
\hline
\end{tabular}

Meanwhile, Table 3 gives an indication of the countries about which most research has been published. For 15 countries, there was just one published research article or paper in the ten-year period. Not surprisingly, the United States accounted for more than 40 per cent of the publications, but it was interesting to see Australia second, with more than double the number of publications of Canada. The United Kingdom accounted for only 6.2 per cent of the published articles and papers. One reason for this may be that British research in library and information science is often funded by organisations such as Resource that expect reports in the form of monographs (see, for example, McNichol, Ghelani, Nankivell \& Shoolbred, 2001; Creaser, 2000; Spreadbury \& Spiller, 1999), rather than articles or papers. 
The works listed as "international" were of two main types: those where data were collected by the author/s in two or more countries; and those the aim of which was to study an international phenomenon. Among the former were the comparative studies of principal support for school library programs, conducted by Oberg in Canada and Henri and Hay in Australia (see, for example, Oberg, Hay \& Henri, 2000) and an article by Tallman and Henderson (1999) that reported on an American project that was replicated in Australia. Among the latter were Knuth's articles reporting on aspects of her study of the International Association of School Librarianship (see, for example, Knuth, 1996), and the author's own study of school library home pages on the Internet (see, for example, Clyde, 1999).

\section{Research Methods Used in School Librarianship}

The fifth aim that guided this section of the overall research about "Research and Researchers in School Librarianship" was "to identify the research methodologies that are being used by researchers in the field of school librarianship and to investigate any changes over time". In order to do this, the classification of research strategies developed by Järvelin \& Vakkari (1990) was used. This provides the basis for Table 4 (which shows the primary methodologies used for research in school librarianship over the decade) and Table 5 (which provides the basis for a comparison of research in school librarianship with international and national studies of research in library and information science in general). Järvelin and Vakkari also provide a classification for data collection methods; although this was used to analyse the research in school librarianship, lack of space precludes reporting on this aspect here. However, Table 6 reports on the number of data collection methods used in each study over the ten years.

Throughout the decade, the research method most commonly used as the main method for projects reported in school librarianship was the survey $(39.1 \%$ of the articles and papers over the decade) though it declined in popularity from 45.9 per cent in 1991-1995 to 35.3 per cent in 1996-2000. Overall, this is also a further decline from the period 1987 to 1991, when "more than three-fourths of the research" in school librarianship relied upon one method, the questionnaire survey (Grover \& Fowler, 1993, p.243). There is nothing inherently wrong with survey research; indeed it is sometimes the best method for dealing with a particular research problem. On the other hand, over-reliance on one research methodology is unhealthy for the profession for two main reasons: one methodology cannot be used to explore all aspects of research problems; and some problems may never be addressed simply because the survey method could not be used to address them.

The second most commonly-used methodology in the reported research in school librarianship through the decade was qualitative methods (19.6\%). Although Table 4 suggests that qualitative methods were used consistently through the decade, a breakdown by year shows that the use of qualitative methods gradually increased through the first five years, but it was not until 1995 that qualitative methods became relatively popular: they were used in five per cent of the published research in 1991; 3.8 per cent in 1992; 13.3 per cent in 1993; 14.7 per cent in 1994; and 33.3 per cent in 1995. On the other hand, they seem to have reached their peak in 1995, though they were used consistently through the second five yearperiod. Other methods used through the decade included case studies and action research, experimental research, content analysis, and literature reviews, through none were nearly as popular as surveys and qualitative methods. On the other hand, several methods in the 
Järvelin and Vakkari classification were not used at all (as the primary method for a project) through the ten years.

Table 4

Research Methods Used in School Librarianship Research

(Classification of Järvelin and Vakkari)

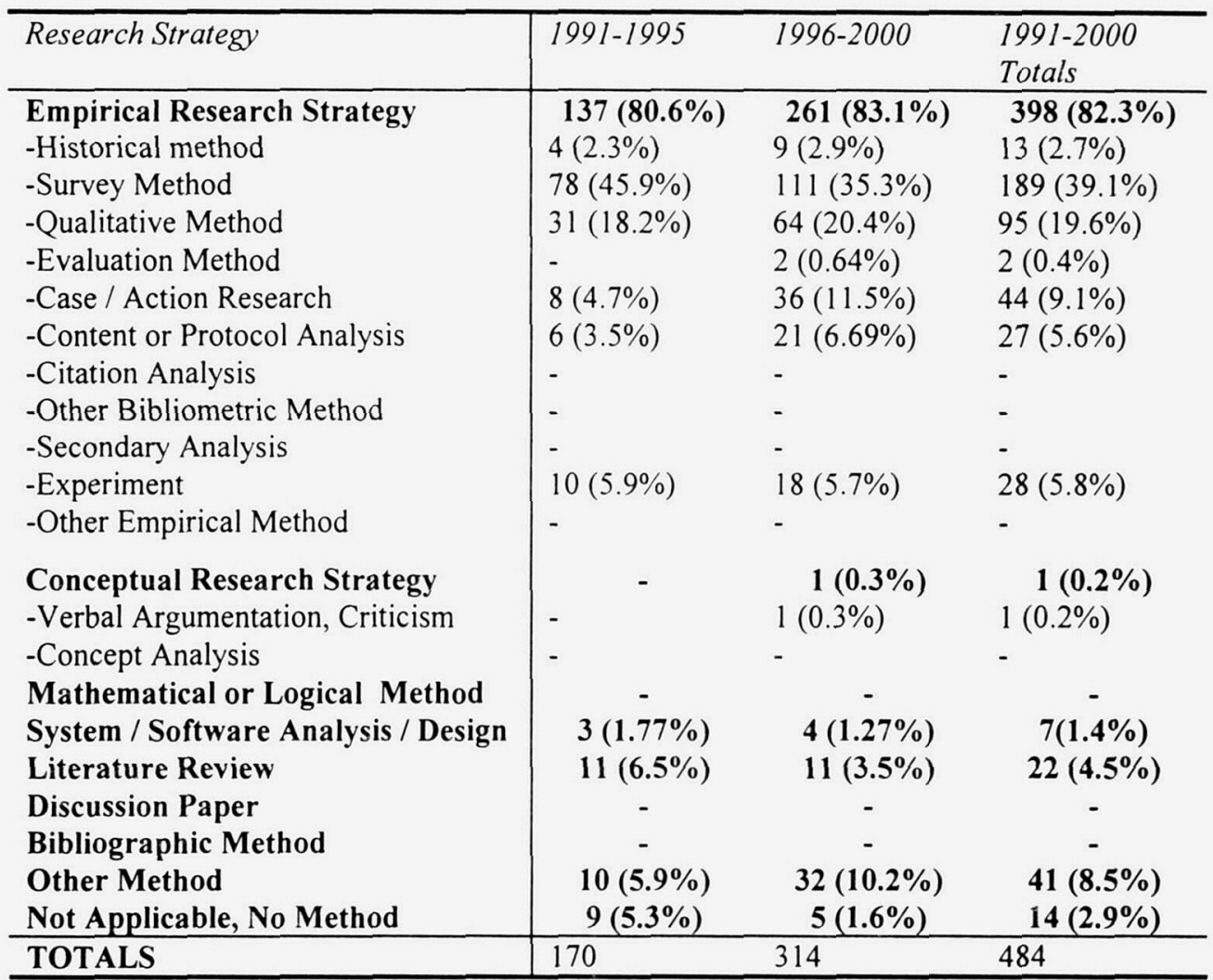

Note 1: Järvelin and Vakkari's research strategies classification as presented in Rochester \& Vakkari, 1998.

The results of four studies that used the Järvelin and Vakkari classification of research strategies are compared in Table 5. The first is Järvelin and Vakkari's international study of articles in core library and information science journals; the second is a national study of the published research literature of library and information science in Iceland; the third is a national study of library and information science theses and dissertations in Turkey; and the third is the present international study of research articles and conference papers in school librarianship. The two national studies were selected for this comparison because they both included school librarianship as part of library and information science in general. In all four, the survey method is dominant, to the greatest extent in the national studies of Iceland and Turkey and to a lesser extent in the two international studies. School librarianship, though probably overly dependent on survey research, is nevertheless comparatively in a better position than one might expect. 
Table 5 .

Research Methods Used in Four Studies

(Classification of Järvelin and Vakkari)

\begin{tabular}{|c|c|c|c|c|}
\hline Research Strategy & $\begin{array}{l}\text { Järvelin \& } \\
\text { Vakkari, } \\
1990\end{array}$ & $\begin{array}{l}\text { Iceland } \\
\text { (Gu,brands. } \\
\text { et al. 2001) }\end{array}$ & $\begin{array}{l}\text { Turkey } \\
\text { (Yontar, } \\
\text { 1995) }\end{array}$ & $\begin{array}{l}\text { School } \\
\text { Libraries } \\
1991-2000 \\
\text { (Clyde) }\end{array}$ \\
\hline Empirical Research Strategy & $55.9 \%$ & $100 \%$ & $81 \%$ & $82.3 \%$ \\
\hline -Historical method & $10.7 \%$ & $8.8 \%$ & $12.7 \%$ & $2.7 \%$ \\
\hline -Survey Method & $22.9 \%$ & $67.6 \%$ & $59.1 \%$ & $39.1 \%$ \\
\hline -Qualitative Method & $1.6 \%$ & $3.0 \%$ & - & $19.6 \%$ \\
\hline -Evaluation Method & $5.6 \%$ & - & - & $0.4 \%$ \\
\hline -Case / Action Research & $3.8 \%$ & - & $1.82 \%$ & $9.1 \%$ \\
\hline -Content or Protocol Analysis & $1.1 \%$ & $17.6 \%$ & $4.55 \%$ & $5.6 \%$ \\
\hline -Citation Analysis & $3.3 \%$ & $3.0 \%$ & - & - \\
\hline -Other Bibliometric Method & $0.9 \%$ & - & - & - \\
\hline -Secondary Analysis & - & - & - & - \\
\hline -Experiment & $1.6 \%$ & - & $2.73 \%$ & $5.8 \%$ \\
\hline -Other Empirical Method & $4.5 \%$ & - & - & - \\
\hline Conceptual Research Strategy & $23.4 \%$ & $3.7 \%$ & & $0.2 \%$ \\
\hline -Verbal Argumentation, Criticism & $22.5 \%$ & - & - & $0.2 \%$ \\
\hline -Concept Analysis & $0.9 \%$ & $3.7 \%$ & - & - \\
\hline Mathematical or Logical Method & $2.7 \%$ & - & $2.7 \%$ & - \\
\hline System / Software Analysis / Design & $14.5 \%$ & - & $3.6 \%$ & $1.4 \%$ \\
\hline Literature Review & $2.7 \%$ & - & $2.7 \%$ & $4.5 \%$ \\
\hline Discussion paper & - & - & - & - \\
\hline Bibliographic Method & - & - & $5.5 \%$ & - \\
\hline Other Method & - & - & $4.5 \%$ & $8.5 \%$ \\
\hline Not Applicable, No Method & - & & - & $2.9 \%$ \\
\hline TOTALS & 449 & 34 & 110 & 484 \\
\hline
\end{tabular}

Note 1: Column 1: Järvelin and Vakkari's research strategies classification as presented in Rochester \& Vakkari, 1998.

Note 2: Column 2: Järvelin and Vakkari studied research articles in 37 core LIS journals.

Note 3: Column 3: Gu>brandsdóttir et al. (2001) studied published research in library and information science in Iceland, 1994-2000 (including books, chapters, articles and conference papers)

Note 4: Column 4: Yontar (1995) studied theses and dissertations presented for higher degrees in LIS in

Turkey

Note 5: Column 5: The international study of research articles and papers in school librarianship, 1991-2000 (Clyde)

Note 6: All results are reported in percentages because Järvelin and Vakkari, in their original study (1990) used percentages only, with the total number of items studied noted at the bottom of each column. For the results to be comparable, subsequent studies that use the same methodology are reported in the same way.

There has been more use of qualitative methods in school library research through the 1990s than in librarianship in general; only three per cent of published Icelandic research used qualitative methods, while none of the Turkish studies used qualitative methods. Researchers in school librarianship, in comparison with the researchers in the two national studies, have shown themselves willing to adopt the newer methods of qualitative research. Researchers in school librarianship have also been more willing to use action research and "other methods" (including comparative methods and Delphi techniques, among others). In addition, Table 6 shows that many studies are employing multiple methods. 
Table 6

Number of Data Collection Methods Used in Each Research Study

\begin{tabular}{l|lllll}
\hline YEAR & One Method & Two Methods & Three Methods & $\begin{array}{l}\text { More than } \\
\text { Three Methods }\end{array}$ & Unclassifiable \\
\hline 1991 & $18(90 \%)$ & - & $1(5 \%)$ & - & $1(5 \%)$ \\
1992 & $21(80.8 \%)$ & $2(7.7 \%)$ & $1(3.8 \%)$ & $1(3.8 \%)$ & $1(3.8 \%)$ \\
1993 & $21(70 \%)$ & - & $5(16.6 \%)$ & $1(3.3 \%)$ & $3(10 \%)$ \\
1994 & $21(61.8 \%)$ & $4(11.8 \%)$ & $6(17.6 \%)$ & - & $3(8.8 \%)$ \\
1995 & $36(60 \%)$ & $8(13.3 \%)$ & $10(16.7 \%)$ & $4(6.6 \%)$ & $2(3.3 \%)$ \\
$\mathbf{1 9 9 1 - 1 9 9 5}$ & $\mathbf{1 1 7 ( 6 8 . 8 \% )}$ & $\mathbf{1 4 ( 8 . 2 \% )}$ & $\mathbf{2 3}(\mathbf{1 3 . 5} \%)$ & $\mathbf{6 ( 3 . 5 \% )}$ & $\mathbf{1 0 ( 5 . 9 \% )}$ \\
1996 & $35(63.6 \%)$ & $6(10.9 \%)$ & $8(14.5 \%)$ & $5(9.1 \%)$ & $1(1.8 \%)$ \\
1997 & $41(62.1 \%)$ & $9(13.6 \%)$ & $8(12.1 \%)$ & $6(9.1 \%)$ & $2(3 \%)$ \\
1998 & $45(73.8 \%)$ & $6(9.8 \%)$ & $7(11.5 \%)$ & $3(4.9 \%)$ & - \\
1999 & $30(40.5 \%)$ & $9(12.2 \%)$ & $11(14.9 \%)$ & $19(25.7 \%)$ & $5(6.8 \%)$ \\
2000 & $31(53.4 \%)$ & $5(8.6 \%)$ & $6(10.3 \%)$ & $13(22.4 \%)$ & $3(5.2 \%)$ \\
$\mathbf{1 9 9 6 - 2 0 0 0}$ & $\mathbf{1 8 2 ( 5 7 . 9 \% )}$ & $\mathbf{3 5}(\mathbf{1 1 . 1 \% )}$ & $\mathbf{4 0}(\mathbf{1 2 . 7 \% )}$ & $\mathbf{4 6}(\mathbf{1 4 . 6 \% )}$ & $\mathbf{1 1 ( 3 . 5 \% )}$ \\
\hline $\mathbf{1 9 9 1 - 2 0 0 0}$ & $\mathbf{2 9 9 ( 6 1 . 8 \% )}$ & $49(10.1 \%)$ & $63(13 \%)$ & $52(10.7 \%)$ & $21(4.3 \%)$ \\
\hline
\end{tabular}

\section{Research Topics In School Librarianship}

The sixth aim that guided this section of the overall research about "Research and Researchers in School Librarianship" was "to identify the topics that are being studied by researchers in the field of school librarianship and to investigate any changes over time". In order to do this, the classification of research topics developed by Järvelin \& Vakkari (1990) was used. This provides the basis for Table 7 (which shows the main topics that were the focus for research in school librarianship over the decade). As was the case for the research methods (above), a comparative table was also developed for research topics across a number of national and international studies of research in library and information science in general. Unfortunately the results of this analysis were less clear-cut than those for the research methods, and so, after further work on this aspect, the comparative work related to research topics will be presented elsewhere. In this section of the paper, only the analysis of research topics in school librarianship through the decade of the 1990s will be discussed.

The research topics classification developed by Järvelin and Vakkari is based on a hierarchical structure of categories and sub-categories that cover the broad field of library and information science. Järvelin and Vakkari used it in their own studies (1990;1993), and it was used (with adaptations for the local setting) by Cano and Rey (1993) in their Spanish study. Some other researchers, however, have used only the main topics in the Järvelin and Vakkari classification, either because of the small number of research publications being analysed (for example, Pálsdóttir, et al., 1997) or for brevity in reporting (for example, Yontar \& Yalvaç, 2000). Although the research articles and papers in school librarianship were analysed for this present study using the full classification, the results are reported here using the main topics, for the sake of brevity. 
Table 7

Research Topics in School Librarianship

(Classification of Järvelin and Vakkari)

\begin{tabular}{l|lll}
\hline Research Topic & $1991-1995$ & $1996-2000$ & $\begin{array}{l}1991-2000 \\
\text { Totals }\end{array}$ \\
\hline The Profession & $15(8.8 \%)$ & $34(10.8 \%)$ & $49(10.1 \%)$ \\
Library History & $1(0.6 \%)$ & $4(1.3 \%)$ & $5(1 \%)$ \\
Publishing & - & - & - \\
Education in LIS & $8(4.7 \%)$ & $14(4.5 \%)$ & $22(4.5 \%)$ \\
Methodology & - & - & - \\
Analysis of LIS & $2(1.6 \%)$ & $2(0.6 \%)$ & $4(0.8 \%)$ \\
Library \& Information Service Activities & $16(9.4 \%)$ & $30(9.6 \%)$ & $46(9.5 \%)$ \\
Information Storage and Retrieval & $4(2.4 \%)$ & $2(0.6 \%)$ & $6(1.2 \%)$ \\
Information Seeking & $17(10 \%)$ & $25(7.9 \%)$ & $42(8.6 \%)$ \\
Scientific \& Professional Communication & $1(0.6 \%)$ & - & $1(0.2 \%)$ \\
Other Aspects of LIS & $19(11.1 \%)$ & $25(7.9 \%)$ & $44(9 \%)$ \\
Other Studies & - & $1(0.3 \%)$ & $1(0.2 \%)$ \\
Added: National Survey & $5(2.9 \%)$ & $12(3.8 \%)$ & $17(3.5 \%)$ \\
Added: Information Skills/Literacy & $35(20.6 \%)$ & $79(25.2 \%)$ & $114(23.6 \%)$ \\
Added: Principal Support & $2(1.2 \%)$ & $15(4.8 \%)$ & $17(3.5 \%)$ \\
Added: Information Technology & $23(13.5 \%)$ & $29(9.2 \%)$ & $52(10.7 \%)$ \\
Added: Censorship & $8(4.7 \%)$ & $6(1.9 \%)$ & $14(2.9 \%)$ \\
Added: Reading \& Reading Promotion & $14(8.2 \%)$ & $36(11.5 \%)$ & $50(10.3 \%)$ \\
\hline TOTALS & 170 & 314 & 484 \\
\hline
\end{tabular}

It is clear from Table 7 that Järvelin and Vakkari's research topics classification is not a particularly "good fit" for the published research in school librarianship in the period under study. Six topics have been added to the classification to accommodate important areas of research in school librarianship, while nine per cent of all research articles and papers are classified under "Other aspects of LIS". It is tempting to say that this is evidence that school libraries are significantly different from other kinds of libraries; however, it may be just that the research priorities in school librarianship are different. Some of the national general studies based on the Järvelin and Vakkari methodology have added additional topics to the classification to take account of local research emphases (for example the addition of research in reading for the Icelandic study of Pálsdóttir, et al. 1994). However, none of the national studies made additions on the scale that were necessary for this study of school librarianship research.

In their international study of research in library and information science in general (1990), Järvelin and Vakkari found that the most popular areas of research were information storage and retrieval (29.2\%) and library and information service activities (27.2\%). In this present international study of research in school librarianship, the most popular area of research was information skills and information literacy (23.6\% over the decade). Järvelin and Vakkari include "user education" in their category of "Library and information service activities", and while some of the school librarianship research could be classified there, the information skills and information literacy research that is being undertaken in the field of school librarianship goes well beyond library (and information) user education. It also goes beyond the "information seeking behaviour" that is part of the "Information seeking" category. The emphasis on information skills and information literacy research increased through the decade, too, from 15 per cent of the total in 1991 to 24.1 per cent in 2000 (and reaching a high of 27.9 per cent in 1998). Further, the emphasis seems relatively new: in their 
study of school librarianship research from 1987 to 1991, Grover and Fowler (1993) found only 33 of 153 studies dealing with school library clientele, of which only a few focused on "learning information skills" and related topics.

Other topics that were each the focus of more than ten per cent of the studies through the 1990s were information technology (while aspects of information technology are catered for in various parts of the Järvelin and Vakkari classification, and some studies were placed there, many of the studies of information technology in school librarianship took a much wider approach, covering IT as a whole), reading and reading promotion in the context of the school library (again, taking a wider approach than that implied in the category "Library and information service activities"), and studies of the profession (in particular, studies of the role or characteristics of the school librarians). Principal support for school libraries was added to the classification because the research that is being undertaken in this field does not fit easily into any part of the Järvelin and Vakkari classification. Research on censorship in relation to school libraries has been a minor but ongoing concern through the decade. The national surveys of school libraries that are so important for planning, stand out because of their wideranging approach and their methodology. In addition, the topics included in the Järvelin and Vakkari classification "Other Aspects of LIS" give an indication of the different research concerns in the field of school librarianship; among other topics, we find school library standards, central support services for school libraries, school and public library cooperation, national and state school library policy, cooperative planning and teaching in the school, and international aid to school libraries in developing countries.

\section{Discussion}

The classifications developed by Järvelin and Vakkari (1990) proved useful as a tool for analysing research methodologies employed in school librarianship over time and across national boundaries. The classifications were less helpful in analysing research topics, though their use did serve to highlight the different topics that concern researchers in school librarianship as against the research in library and information science as a whole. The application of these widely-accepted classifications to research in school librarianship provided a means for considerilig research in school librarianship in a wider context.

This study of research in school librarianship shows that the amount of published research (in the form of journal articles and published conference papers) has increased more than one hundred per cent over the decade 1991 to 2000 . However, it would be wrong to conclude that this represents a proportional increase in the amount of research actually carried out through the period. A parallel analysis (in progress) of the authors of the published research suggests that there are now both more authors publishing the results of school library research and the more prolific of those authors are publishing more. Again, though, it would be wrong to conclude that this represents a proportional increase in the amount of research undertaken by each author. What we are seeing evidence of here is an increase in research publishing; further analyses would be needed to confirm that these results represent more research actually being undertaken.

This documented increase in research publishing may be influenced by a number of factors. The establishment of several research grants in the field of school librarianship (including the two research grants offered each year by IASL, and those offered by the American Association of School Librarians and the Canadian Library Association) usually carry the expectation the results of the research will either be presented in the form of a 
conference paper or as an article in the Association's journal. There are now more places in which research in the field of school librarianship can be published: for example, IASL's research journal School Libraries Worldwide was established in 1995, and the series of Research Forums associated with the annual conferences, in 1997. The American Association of School Librarians' professional periodical School Library Media Quarterly became a research journal under the title School Library Media Research (in 1999). A number of other professional journals have established regular research columns (for example, Access and Scan in Australia and Knowledge Quest in the United States). In addition there are wider trends at work that are reinforcing the need to carry out and publish research, including an emphasis on action research and evidence-based practice in education.

This research project has not so far addressed the issue of the quality of the research that is being published in the field of school librarianship, though it is an issue that has to be faced if we expect that the profession's research will influence decision-makers. Between 1991 and the end of 2000 , only a relatively small proportion (58 articles of 389 , or $14.9 \%$; see the table in Appendix 1) of the research articles in school librarianship were published in journals that are on the ISI (Institute of Scientific Information) Master Journal List (an indicator of quality that is accepted by many universities for purposes of faculty evaluation). However, this Master Journal List omits the two major research journals in the field of school librarianship, School Libraries Worldwide and School Library Media Research, both peerrefereed journals of obvious quality, that attract articles from the best-known researchers in the profession.

There are indicators of problems with research quality across a range of fields (not just in school librarianship). Some of those problems are blamed on the very factors that are sometimes seen as indicators of progress, such as the amount of research publishing and the increase in the numbers of places where research can be published (Katzer, Cook, \& Crouch, 1997, p.6). For example, Danish research has shown that increasing pressure on academics to publish and systems that reward those who publish the most (regardless of quality) are leading to recycling of research results and multiple articles being published about the one project (Jongsma, 2001). This means that the number of publications appearing each year becomes a less reliable indicator of research actually undertaken, while at the same time it raises questions about the overall quality of what is published.

On the other hand, there are also indicators of progress in research in the field of school librarianship. Haycock has described "a rich body of research in school librarianship" (Morton, 1997, p.31), and has promoted it through his What Works book (Haycock, 1992) and "What Works" columns, which summarise current research findings of interest to school librarians. This present study of research in school librarianship has suggested some signs of progress in the last decade. Not only is the number of articles and conference papers published each year increasing, but a greater range of research methodologies is being used by researchers. While the survey method remains dominant (and has its strengths), other methods are becoming more common. It is also becoming more common for researchers to use triangulation - a range of data collection methodologies applied within the one project to gain a better picture of the phenomenon under study. In terms of research topics, there are studies that are looking at fundamental questions for school librarians, such as the nature of information skills and how those skills are best acquired; apart from that, there is a healthy variety in the topics being addressed through research. 


\section{The Next Steps}

This paper has reported on one aspect of the wider longitudinal study that is looking at "Research and Researchers in School Librarianship". It has provided a view of trends in research in our profession over a decade, with a focus on where the research is published, the topics that are researched, and the methods used by researchers. The next stage of the ongoing project will take up other issues raised in the paper presented as part of the Research Forum at the 2001 IASL conference (Clyde, 2001a). In particular, it will investigate the researchers themselves, their perceptions of the factors that either promote or inhibit the conduct of research in school librarianship, and their ideas about research quality. A set of data collection instruments is under development as this paper is being written; this aspect of the work will be completed by the time the paper is presented in August 2002.

\section{References}

Bell, E. (2002, March 18). Teachers, music, libraries in peril as schools retrench: Economic woes force districts into painful classroom cutbacks. San Francisco Chronicle, http://www.sfgate.com/cgi-bin/article.cgi?file=/c/a/2002/03/18/MN146449.DTL (accessed 18 March 2002).

Blöndal, R. (1997). Icelandic research in library and information science from 1964 to 1994. BA Project, Library and Information Science Department, The University of Iceland.

Buckley, J. (1995, June). Reflections on the role of research. Scan, 14(2), 25-27.

Calvert, P. J. (1990, December). Library literature in New Zealand: A critique. New Zealand Libraries, 46(7/8), 19-21.

Cano, V., \& Rey, C. (1993). Ten years of Spanish library and information science research: A bibliometric study. Paper presented at the $59^{\text {th }}$ IFLA Conference, Barcelona, Spain, August 1003. [197-THEOR-E]

CBC News (2002, March 11). Coalition says there's a crisis in Canada's school libraries. CBC News Online. http://www.cbc.ca/stories/2002/03/11/libraries020311 (accessed 13 March 2002).

Clyde, L.A. (1994). Survey of the literature on national school library surveys. In S.K. Hannesdóttir (Ed.), Guidelines for conducting national surveys of school libraries and their needs (pp.1-26). Paris: UNESCO.

Clyde, L.A. (Ed.). (1996). Sustaining the vision: A collection of articles and papers on research in school librarianship, in honor of Jean E. Lowrie. Castle Rock, CO: Hi Willow Research and Publishing for the International Association of School Librarianship.

Clyde, L.A. (1999). The school library: On the information highway or stalled in the carpark? In L. Lighthall \& E. Howe (Eds.), Unleash the power! Knowledge, technology, diversity: Papers presented at the Third International Forum on Research in School Librarianship (pp.227-237). Seattle, WA: International Association of School Librarianship. 
Clyde, L.A. (2001a). Behind the inspiring connections: Research and researchers in school librarianship. A progress report. In P. Hughes \& L. Selby (Eds.), Inspiring connections: Learning, libraries and literacy, Proceedings of the Fifth International Forum on Research in School Librarianship... Auckland, New Zealand, 9-12 July 2001 (pp.65-77). Seattle, WA: International Association of School Librarianship.

Clyde, L.A. (2001b). Behind the inspiring connections: Research and researchers in school librarianship. A progress report. Presentation given at the Fifth International Forum on Research in School Librarianship, Auckland, New Zealand, 9-12 July. Recorded at Waipuna Hotel and Conference Centre, July 2001 [audiocassette].

Coleman, S. (2000, June). Librarianship and information science in Islamic East Africa 19661999: An annotated bibliography. International Information and Library Review, 32(4), 149-211.

Creaser, C. (2000). A survey of library services to schools and children in the UK 1999-2000. Library and Information Commission Research Report 90. Loughborough: Library and Information Statistics Unit.

Durand, M., \& Daschko M.W. (2001, September). Elementary and secondary schools: The role, challenges and financial conditions of school and school library resources in Canada: A report. http://www.nlc-bnc.ca/9/14/index-e.html (accessed 14 February 2002).

Grover, R., \& Fowler, S.G. (1993, Summer). Recent trends in school library media research. School Library Media Quarterly, 21(4), 241-247.

Gu〉brandsdóttir, E.K., Halldórsdóttir, H., Magnúsdóttir, K., Ísaksen, M., Jónsdóttir, R., Sighvatsdóttir, S.J., Guınadóttir, S., Ólafsdóttir, S., \& Clyde, L.A. (2001). Recent published research in library and information science related to Iceland: Topics and methods. http://www.hi.is/ anne/lis2001.html (accessed 5 May 2002).

Hawkins, D.T. (2001). Bibliometrics of electronic journals in information science. Information Research, 7(1). http://InformationR.net/ir/7-1/paper120.html (accessed 20 November 2001).

Haycock, K. (1992). What works: Research about teaching and learning through the school's library resource center. Seattle, WA: Rockland Press.

Henri, J. (1998). The research window: The case for research. Access, 12(3), 33.

Institute of Scientific Information (2002). ISI Master Journal List. http://www.isinet.com/ (accessed 22 March 2002).

Järvelin, K., \& Vakkari, P. (1990). Content analysis of research articles in library and information science. Library and Information Science Research, 12(4), 395-421.

Järvelin, K., \& Vakkari, P. (1993). The evolution of library and information science 19651985: A content analysis of journal articles. Information Processing and Management, 29(1), 129-144. 
Jongsma, A. (2001, January 26). Re-user friendly data. The Times Higher Education Supplement, 21.

Katzer, J. (1989). ALA and the status of research in library/information science. Library and Information Science Research, 11, 83-87.

Katzer, J., Cook, K.H., \& Crouch, W.W. (1997). Evaluating information. (4 ${ }^{\text {th }}$ ed.). Boston, MA: McGraw-Hill.

Knuth, R. (1996, July). Through members' eyes: A survey of the membership of the International Association of School Librarianship. School Libraries Worldwide, 2(2), $33-53$.

Layzell Ward, P. (1995). The nature of UK research literature: Some thoughts arising from a bibliometric study. Paper for the Open Forum, Library Theory and Research Section, IFLA General Conference, Copenhagen, 1997.

McNichol, S., Ghelani, T., Nankivell, C., \& Shoolbred, M. (2001). Children, access and learning: Resource-based learning and the impacts of environment and learning cultures. Library and Information Commission Research Report 119. London: Resource, The Council for Museums, Archives and Libraries.

Morton, E. (1997, May). School library research: A Canadian perspective. Feliciter, 43(5), 30-31, 49.

Oberg, D., Hay, L., \& Henri, J. (2000). The role of the principal in an information literate school community: Cross country comparisons from an international research project. School Library Media Research, 3, http://www.ala.org/aasl/SLMR/principal2/principal2_main.html (accessed 7 May 2002).

Pálsdóttir, G., Árnadóttir, I., Sverrisdóttir, I., Blöndal, R., \& Clyde, L.A. (1994). Rannsóknir í bókasafns- og upplłsingafræ >i : Ísland. Bókasafni >, 18, 38-43.

Pálsdóttir, G., Árnadóttir, I., Sverrisdóttir, I., Blöndal, R., \& Clyde, L.A. (1997). Published research about library and information science in or related to Iceland. Nordic Yearbook of Library, Information and Documentation Research. Oslo: Novus forlag, 85-108.

Rochester, M. (1995, September). Library and information science research in Australia 1985-1994: A content analysis of research articles in The Australian Library Journal and Australian Academic and Research Libraries. Australian Academic and Research Libraries, 26, 163-170.

Rochester, M., \& Vakkari, P. (1998). International LIS research: A comparison of national trends. IFLA Journal, 24(3), 166-175.

Satija, M.P. (1994, Spring). Bibliographies of Indian library science: A literature review. Third World Libraries, 4(2), 9-17. 
Clyde

Singh, S., \& Singh, S. (1990, July-October). Library and information science periodicals in India. Herald of Library Science, 29(3-4), 200-212.

Snelson, P., \& Talar, A.S. (1991, September). Content analysis of ACRL conference papers. College and Research Libraries, 52(5), 466-472.

Spreadbury, H., \& Spiller, D. (1999). Survey of secondary school library users. Library and Information Commission Research Report 9. Loughborough: Loughborough University Library and Information Statistics Unit.

Stroud, J.C. (1982, Winter). Research methodology used in school library dissertations. School Library Media Quarterly, 10(2), 124-134.

Tallman, J.I., \& Henderson, L. (1999). Constructing mental model paradigms for teaching electronic resources. School Library Media Research, 2, http://www.ala.org/aasl/SLMR/mental.html (accessed 7 May 2002).

Todd, R. J. (2002, February). Evidence based practice: The sustainable future for teacherlibrarians. Scan, 21(1), 30-37.

Yontar, A. (1995). Main research trends being investigated in Turkey as revealed in graduate theses. Booklet 7, Division of Education and Research, $61^{\text {st }}$ IFLA General Conference, Istanbul, Turkey, 20-26 August 1995. [137-LTR-3-E]

Yontar, A., \& Yalvaç, M. (2000). Problems of library and information science research in Turkey: A content analysis of journal articles 1952-1994. IFLA Journal, 26(1), 39-51. 


\section{APPENDIX 1 \\ JOURNALS AND PUBLISHED CONFERENCE PROCEEDINGS FROM WHICH ARTICLES / PAPERS HAVE BEEN SELECTED}

\section{Journals ${ }^{1}$}

\begin{tabular}{|c|c|c|c|c|c|}
\hline Journal & $\begin{array}{l}\text { No. of } \\
\text { Articles } \\
1991- \\
1995\end{array}$ & $\begin{array}{l}\text { No. of } \\
\text { Articles } \\
1996- \\
2000\end{array}$ & $\begin{array}{l}\% \\
\text { Change }\end{array}$ & $\begin{array}{l}\text { Total No. } \\
\text { of } \\
\text { Articles } \\
1991- \\
2000\end{array}$ & $\begin{array}{l}\text { Listed in } \\
\text { ISI } \\
2002 ?^{2}\end{array}$ \\
\hline $\begin{array}{l}\text { 1. School Library Media Quarterly / } \\
\text { School Library Media Research }\end{array}$ & $\begin{array}{l}42 \\
(27.3 \%)\end{array}$ & $\begin{array}{l}37 \\
(15.7 \%)\end{array}$ & $-7.0 \%$ & $\begin{array}{l}79 \\
(20.3 \%)\end{array}$ & no \\
\hline 2. School Libraries Worldwide ${ }^{4}$ & $\begin{array}{l}8 \\
(5.2 \%)\end{array}$ & $\begin{array}{l}41 \\
(17.4 \%)\end{array}$ & $7.4 \%$ & $\begin{array}{l}49 \\
(12.6 \%)\end{array}$ & no \\
\hline 3. Scan & $\begin{array}{l}3 \\
(1.9 \%)\end{array}$ & $\begin{array}{l}17 \\
(7.2 \%)\end{array}$ & $3.2 \%$ & $\begin{array}{l}20 \\
(5.1 \%)\end{array}$ & no \\
\hline 4. Access & $\begin{array}{l}6 \\
(3.9 \%)\end{array}$ & $\begin{array}{l}12 \\
(5.1 \%)\end{array}$ & $0.7 \%$ & $\begin{array}{l}18 \\
(4.6 \%)\end{array}$ & no \\
\hline 5. School Library Journal & $\begin{array}{l}5 \\
(3.2 \%)\end{array}$ & $\begin{array}{l}13 \\
(5.5 \%)\end{array}$ & $1.4 \%$ & $\begin{array}{l}18 \\
(4.6 \%)\end{array}$ & no \\
\hline $\begin{array}{l}\text { 6. Journal of the American Society for } \\
\text { Information Science JASIS }\end{array}$ & $\begin{array}{l}4 \\
(2.6 \%)\end{array}$ & $\begin{array}{l}11 \\
(4.7 \%)\end{array}$ & $1.2 \%$ & $\begin{array}{l}15 \\
(3.8 \%)^{6}\end{array}$ & yes \\
\hline $\begin{array}{l}\text { 7. Emergency Librarian / Teacher } \\
\text { Librarian }^{\text {? }}\end{array}$ & $\begin{array}{l}5 \\
(3.2 \%)\end{array}$ & $\begin{array}{l}9 \\
(3.8 \%)\end{array}$ & $0.4 \%$ & $\begin{array}{l}14 \\
(3.6 \%)\end{array}$ & no \\
\hline $\begin{array}{l}\text { 8. Journal of Youth Services in } \\
\text { Libraries }\end{array}$ & $\begin{array}{l}9 \\
(5.8 \%)\end{array}$ & $\begin{array}{l}5 \\
(2.1 \%)\end{array}$ & $-2.2 \%$ & $\begin{array}{l}14 \\
(3.6 \%)\end{array}$ & no \\
\hline 9. Education Libraries Journal & $\begin{array}{l}9 \\
(5.8 \%)\end{array}$ & $\begin{array}{l}4 \\
(1.7 \%)\end{array}$ & $-2.5 \%$ & $\begin{array}{l}13 \\
(3.3 \%)\end{array}$ & no \\
\hline $\begin{array}{l}\text { 10. Library and Information Science } \\
\text { Research LISR }\end{array}$ & $\begin{array}{l}4 \\
(2.6 \%)\end{array}$ & $\begin{array}{l}8 \\
(3.4 \%)\end{array}$ & $0.5 \%$ & $\begin{array}{l}12 \\
(3.1 \%)\end{array}$ & yes \\
\hline 11. Knowledge Quest & - & 10 & & 10 & no \\
\hline 12. Orana & 1 & 8 & & 9 & no \\
\hline $\begin{array}{l}\text { 13. South African Journal of Library } \\
\text { and Information Science }\end{array}$ & 3 & 6 & & 9 & no \\
\hline 14. Library Trends & 2 & 5 & & 7 & yes \\
\hline 15. School Libraries in Canada & 4 & 3 & & 7 & no \\
\hline 16. Education for Information & 2 & 4 & & 6 & no \\
\hline $\begin{array}{l}\text { 17. Journal of Librarianship and } \\
\text { Information Science }\end{array}$ & 3 & 3 & & 6 & yes \\
\hline 18. The School Librarian & 1 & 5 & & 6 & no \\
\hline 19. Australian Library Review & 5 & - & & 5 & no \\
\hline $\begin{array}{l}\text { 20. The International Information and } \\
\text { Library Review }\end{array}$ & 4 & 1 & & 5 & yes \\
\hline 21. Library Quarterly & - & 5 & & 5 & yes \\
\hline $\begin{array}{l}\text { 22. The New Review of Children's } \\
\text { Literature and Librarianship }\end{array}$ & - & 5 & & 5 & no \\
\hline
\end{tabular}

${ }^{1}$ Note that percentages have been indicated only for the ten journals with the largest number of research articles. After this, the numbers are so small as to make percentages almost meaningless.

${ }^{2}$ Institute of Scientific Information (ISI) Master Journal List, http://www.isinet.com/ (April 2002).

${ }^{3}$ School Library Media Quarterly (SLMQ) was a print journal until 1998, when it became a Web-based journal. In 1999 the name was changed to School Library Media Research (SLMR).

${ }^{4}$ Commenced publication in January 1995.

${ }^{5}$ Since 2001, the Journal of the American Society for Information Science and Technology, JASIST.

${ }^{6}$ Special issue, 50(1), 1999: "Youth Issues in Information Science" (three relevant articles).

${ }^{7}$ Name of journal changed from Emergency Librarian to Teacher Librarian in 1998. 


\begin{tabular}{|c|c|c|c|c|}
\hline 23. Feliciter & $\frac{1}{1}$ & 3 & 4 & no \\
\hline $\begin{array}{l}\text { 24. Scandinavian Public Library } \\
\text { Quarterly }\end{array}$ & 2 & 2 & 4 & no \\
\hline $\begin{array}{l}\text { 25. African Journal of Library, } \\
\text { Archives and Information Science }\end{array}$ & 3 & - & 3 & no \\
\hline $\begin{array}{l}\text { 26. Journal of Education for Library } \\
\text { and Information Science }\end{array}$ & 1 & 2 & 3 & no \\
\hline $\begin{array}{l}\text { 27. Journal of Educational Media and } \\
\text { Library Sciences }\end{array}$ & 1 & 2 & 3 & no \\
\hline 28. Libri & 2 & 1 & 3 & yes \\
\hline $\begin{array}{l}\text { 29. Australasian Public Libraries and } \\
\text { Information Services }\end{array}$ & 1 & 1 & 2 & no \\
\hline 30. Australian Library Journal & - & 2 & 2 & no \\
\hline 31. The Electronic Library & 1 & 1 & 2 & yes \\
\hline 32. Library Review & 2 & - & 2 & no \\
\hline 33. Reference Librarian & 2 & - & 2 & no \\
\hline $\begin{array}{l}\text { 34. RQ / Reference and User Services } \\
\text { Quarterly }^{8}\end{array}$ & 1 & 1 & 2 & yes \\
\hline $\begin{array}{l}\text { 35. Swedish Library Research / } \\
\text { Svensk Biblioteksforskning }\end{array}$ & 2 & - & 2 & no \\
\hline 36. Third World Libraries & 1 & 1 & 2 & no \\
\hline 37. Asian Libraries & 1 & - & 1 & no \\
\hline 38. Canadian Library Journal ${ }^{9}$ & 1 & - & 1 & no \\
\hline 39. The Computing Teacher & 1 & - & 1 & no \\
\hline $\begin{array}{l}\text { 40. Focus on International and } \\
\text { Comparative Librarianship }\end{array}$ & - & 1 & 1 & no \\
\hline 41. IFLA Journal & - & 1 & 1 & no \\
\hline 42. Illinois Libraries & 1 & - & 1 & no \\
\hline 43. Information Searcher & 1 & - & 1 & no \\
\hline $\begin{array}{l}\text { 44. Information Trends News } \\
\text { Magazine }\end{array}$ & 1 & - & 1 & no \\
\hline $\begin{array}{l}\text { 45. Journal of the Hong Kong Library } \\
\text { Association }\end{array}$ & 1 & - & 1 & no \\
\hline 46. Libraries and Culture & 1 & - & 1 & yes \\
\hline $\begin{array}{l}\text { 47. Microcomputers for Information } \\
\text { Management }\end{array}$ & 1 & - & 1 & no \\
\hline 48. Mousaion & 1 & - & 1 & no \\
\hline 49. MultiMedia Schools & - & 1 & 1 & no \\
\hline 50. Nigerian Libraries & 1 & - & 1 & no \\
\hline $\begin{array}{l}\text { 51. Nigerian Library and Information } \\
\text { Science Review }\end{array}$ & 1 & - & 1 & no \\
\hline 52. North Carolina Libraries & 1 & - & 1 & no \\
\hline 53. Public Libraries Journal & 1 & - & 1 & no \\
\hline 54. School Libraries In View & - & 1 & 1 & no \\
\hline 55. World Libraries & - & 1 & 1 & no \\
\hline $\begin{array}{l}\text { Educational Media and Technology } \\
\text { Yearbook } 2000^{10}\end{array}$ & - & 2 & 2 & \\
\hline TOTALS & $\begin{array}{l}154 \\
(100 \%)\end{array}$ & $\begin{array}{l}235 \\
(100 \%)\end{array}$ & $\begin{array}{l}389 \\
(100 \%)\end{array}$ & \\
\hline
\end{tabular}

8 The name of the journal changed from $R Q$ to Reference and User Services Quarterly in 1997.

9 Suspended publication October 1992.

${ }^{10}$ Special issue focusing on school library media centers. 


\section{Conference Proceedings}

\begin{tabular}{|c|c|c|c|c|}
\hline Conference & $\begin{array}{l}\text { No. of Papers, } \\
\text { 1991-1995 }\end{array}$ & $\begin{array}{l}\text { No. of Papers, } \\
\text { 1996-2000 }\end{array}$ & $\%$ Change & $\begin{array}{l}\text { Total No. of } \\
\text { Papers, } 1991- \\
2000\end{array}$ \\
\hline 1. IASL Conferences & $8(50.0 \%)$ & $65(82.3 \%)^{11}$ & $26.8 \%$ & $73(76.8 \%)$ \\
\hline $\begin{array}{l}\text { 2. International Federation of Library } \\
\text { Associations and Institutions } \\
\text { (IFLA) Schools Section }\end{array}$ & $1(6.2 \%)$ & $11(13.9 \%)$ & $6.3 \%$ & $12(12.6 \%)$ \\
\hline $\begin{array}{l}\text { 3. Australian School Library } \\
\text { Association (ASLA) }\end{array}$ & $6(37.5 \%)$ & - & & $6(6.3 \%)$ \\
\hline $\begin{array}{l}\text { 4. Online Information Conferences } \\
\text { (London) }\end{array}$ & $1(6.2 \%)$ & $1(1.2 \%)$ & $-4.1 \%$ & $2(2.1 \%)$ \\
\hline $\begin{array}{l}\text { 5. Australian Library and Information } \\
\text { Association (ALIA) }\end{array}$ & - & $2(2.5 \%)$ & & $2(2.1 \%)$ \\
\hline TOTALS & $16(100 \%)$ & $79(100 \%)$ & & $95(100 \%)$ \\
\hline
\end{tabular}

\footnotetext{
"The first International Forum on Research in School Librarianship was held in Vancouver, Canada, in 1997, in conjunction with the $26^{\text {th }}$ IASL Conference; since that year, the International Research Forum has been a feature of every IASL conference.
} 